\title{
Formation of Acetylenic Acetals by Ring Opening of 1,1,2-Trihalocyclopropanes under Phase-Transfer Conditions
}

\author{
Leiv K. Sydnes ${ }^{*}, \mathrm{a}, \mathrm{b}$ and Einar Bakstad ${ }^{\mathrm{a}}$ \\ ${ }^{a}$ Department of Chemistry, University of Troms $\varnothing$, N-9037 Troms $\emptyset$, Norway and ${ }^{b}$ Department of Chemistry, University \\ of Bergen, Allégt. 41, N-5007 Bergen, Norway
}

\begin{abstract}
Sydnes, L. K. and Bakstad, E., 1996. Formation of Acetylenic Acetals by Ring Opening of 1,1,2-Trihalocyclopropanes under Phase-Transfer Conditions. - Acta Chem. Scand. 50: 446-453 (C) Acta Chemica Scandinavica 1996.

A number of substituted 1,1-dibromo- and 1,1-dichlorocyclopropanes with an additional chlorine or bromine atom attached to C-2 were synthesized in reasonable to good yields by dihalocarbene addition to the corresponding alkenes under phase-transfer conditions. When the trihalides were treated with $50 \%$ aqueous sodium hydroxide in the presence of ethanol, triethylbenzylammonium chloride and dichloromethane, most of the compounds underwent ring opening and afforded mixtures of acetylenic acetals, usually in good yields. The reaction most likely involves cyclopropene intermediates, which in some cases also rearrange to a minor extent to the corresponding vinylcarbenes and afford $\alpha, \beta$ unsaturated aldehydes.
\end{abstract}

When substituted 1,1,2-trihalocyclopropanes (1) are prepared by addition of dihalocarbene to the corresponding haloalkenes under standard phase-transfer conditions, ${ }^{1-4}$ the yields are generally low to moderate. Addition of minor amounts of ethanol to the reaction mixture, a measure which is known to facilitate cyclopropane formation with other alkenes under such conditions, ${ }^{5-7}$ did not improve the outcome of the reaction; on the contrary, the yield dropped in several cases owing to cyclopropane decomposition. ${ }^{4}$ This was most apparent when 1,1,2-tribromo-2-methylcyclopropane (1c) was prepared from 2-bromopropene and bromoform: in the presence of a fair amount of ethanol, 1,1-diethoxy-2butyne (3b) was obtained in isolable quantities. ${ }^{4}$ When larger amounts of ethanol were employed $\mathbf{3 b}$ was the major product, ${ }^{4}$ which indicates that $\mathbf{3 b}$ results from an ethanol-sensitive ring opening of 1c. This was proved experimentally to be the case: in the absence of EtOH 1c is perfectly stable under phase-transfer conditions. ${ }^{4}$ We therefore wanted to investigate if other 1,1,2trihalocyclopropanes could be converted to acetylenic acetals under the same conditions; the results of our studies are reported here.

\section{Results and discussion}

Preparation of trihalides. The cyclopropanes (1) were made by addition of dihalocarbene to the corresponding

\footnotetext{
* To whom correspondence should be addressed at University of Bergen.
}

alkenes under standard phase-transfer conditions (in the absence of ethanol) and using triethylbenzylammonium chloride (TEBA) as catalyst (Scheme 1). ${ }^{8}$ In accordance with previous results obtained under these conditions ${ }^{4}$ the yield of 1 varied considerably, from $69 \%$ in the case of 1,1-dichloro-2-bromo-2,3-dimethylcyclopropane (1n) to $22 \%$ when bromoethene was converted into 2-bromo1,1-dichlorocyclopropane (1b) (Table 1). Generally, the low yields were not caused by formation of by-products, but by low alkene consumption; a considerable amout of unreacted alkene could therefore be recovered, and a material balance of better than $90 \%$ was usually achieved. This is intimately related to the reactivity of the alkenes towards dihalocarbene, which is reduced by interactions between the alkene $\pi$ system and halogen substituent. ${ }^{9-12}$ Such reactions have been reported to be slow in some cases. ${ }^{10-12}$

Other reactions than cyclopropane formation were generally insignificant. The largest amount of by-product was formed when vinyl bromide was converted to 1,1,2-tribromocyclopropane (1a) and furnished a 5\% yield of tetrabromomethane. The tetrabromide is most likely generated by a reaction between tribromomethan-
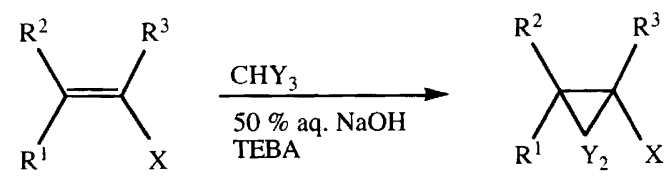
Table 1. 1,1,2-Trihalocyclopropanes obtained by dihalocarbene addition to the corresponding alkenes under phasetransfer conditions in the absence of ethanol.

\begin{tabular}{lllllll}
\hline Compound & $\mathrm{R}^{1}$ & $\mathrm{R}^{2}$ & $\mathrm{R}^{3}$ & $\mathrm{X}$ & $\mathrm{Y}$ & ${\text { Yield }(\%)^{b}}^{b}$ \\
\hline $1 \mathrm{a}$ & $\mathrm{H}$ & $\mathrm{H}$ & $\mathrm{H}$ & $\mathrm{Br}$ & $\mathrm{Br}$ & 30 \\
$1 \mathrm{~b}$ & $\mathrm{H}$ & $\mathrm{H}$ & $\mathrm{H}$ & $\mathrm{Br}$ & $\mathrm{Cl}$ & 22 \\
$1 \mathrm{c}$ & $\mathrm{H}$ & $\mathrm{H}$ & $\mathrm{Me}$ & $\mathrm{Br}$ & $\mathrm{Br}$ & 50 \\
$1 \mathrm{~d}$ & $\mathrm{H}$ & $\mathrm{H}$ & $\mathrm{Me}$ & $\mathrm{Br}$ & $\mathrm{Cl}$ & 50 \\
$1 \mathrm{e}$ & $\mathrm{H}$ & $\mathrm{H}$ & $\mathrm{Me}$ & $\mathrm{Cl}$ & $\mathrm{Br}$ & 51 \\
$1 \mathrm{f}$ & $\mathrm{H}$ & $\mathrm{H}$ & $\mathrm{Me}$ & $\mathrm{Cl}$ & $\mathrm{Cl}$ & 41 \\
$1 \mathrm{~g}$ & $\mathrm{H}$ & $\mathrm{H}$ & $\mathrm{Ph}$ & $\mathrm{Br}$ & $\mathrm{Br}$ & 38 \\
$1 \mathrm{~h}$ & $\mathrm{H}$ & $\mathrm{H}$ & $\mathrm{Ph}$ & $\mathrm{Br}$ & $\mathrm{Cl}$ & 52 \\
$1 \mathrm{i}^{a}$ & $\mathrm{H}$ & $\mathrm{Me}$ & $\mathrm{H}$ & $\mathrm{Br}$ & $\mathrm{Br}$ & 46 \\
$1 \mathrm{j}^{a}$ & $\mathrm{H}$ & $\mathrm{Me}$ & $\mathrm{H}$ & $\mathrm{Br}$ & $\mathrm{Cl}$ & 35 \\
$1 \mathrm{k}^{a}$ & $\mathrm{H}$ & $\mathrm{Me}$ & $\mathrm{H}$ & $\mathrm{Cl}$ & $\mathrm{Br}$ & 48 \\
$1 \mathbf{1}^{a}$ & $\mathrm{H}$ & $\mathrm{Me}$ & $\mathrm{H}$ & $\mathrm{Cl}$ & $\mathrm{Cl}$ & 41 \\
$1 \mathrm{~m}^{a}$ & $\mathrm{H}$ & $\mathrm{Me}$ & $\mathrm{Me}$ & $\mathrm{Br}$ & $\mathrm{Br}$ & 65 \\
$1 \mathrm{n}^{a}$ & $\mathrm{H}$ & $\mathrm{Me}$ & $\mathrm{Me}$ & $\mathrm{Br}$ & $\mathrm{Cl}$ & 69 \\
$1 \mathrm{o}^{a}$ & $\mathrm{H}$ & $\mathrm{Me}$ & $\mathrm{Me}$ & $\mathrm{Cl}$ & $\mathrm{Br}$ & 59 \\
$1 \mathrm{p}^{a}$ & $\mathrm{H}$ & $\mathrm{Me}$ & $\mathrm{Me}$ & $\mathrm{Cl}$ & $\mathrm{Cl}$ & 64 \\
$1 \mathrm{q}$ & $\mathrm{Me}$ & $\mathrm{Me}$ & $\mathrm{H}$ & $\mathrm{Br}$ & $\mathrm{Br}$ & 59 \\
$1 \mathrm{r}$ & $\mathrm{Me}$ & $\mathrm{Me}$ & $\mathrm{H}$ & $\mathrm{Cl}$ & $\mathrm{Br}$ & 63 \\
\hline
\end{tabular}

${ }^{a}$ Mixture of the trans $\left(\mathrm{R}^{1}\right.$ and $\mathrm{R}^{2}$ as written) and cis $\left(\mathrm{R}^{1}\right.$ and $R^{2}$ interchanged) isomers. ${ }^{b}$ Considerable amounts of unreacted haloalkene were recovered in many cases. The material balance was generally better than $90 \%$.

ide and bromoform. ${ }^{13-15}$ Formation of tetrabromomethane has previously been reported to occur during dibromocarbene addition to 1,1,2,2-tetrachloroethene under similar conditions, but tetrabromoethene, formed under those conditions, was not detected in our case. ${ }^{16}$ It is also interesting to note that 1a was not formed when vinyl bromide was allowed to react with dibromocarbene under modified Doering-Hoffmann conditions. ${ }^{17}$

Most of the substrates employed were methylsubstituted haloethene derivatives, but some phenylsubstituted alkenes have been reacted as well. Replacement of a methyl substituent with a phenyl group turned out to influence the outcome of the reaction to a considerable extent. This is indicated by a drop in the cyclopropane yield from $50 \%$ to $38 \%$ when the substrate is changed from 2-bromopropene, yielding 1,1,2-tribromo-2-methylcyclopropane (1c), to 1-bromo-1-phenylethene, giving 1,1,2-tribromo-2-phenyl-cyclopropane (1g). However, the influence becomes abundantly clear when a cis/trans mixture of 1-bromo-2-phenylethene was treated with dibromocarbene under the same conditions; no reaction whatsoever took place in spite of the fact that 1-bromo-1-propene gave a $46 \%$ yield of 1,1,2-tribromo-3-methylcyclopropane (1i). This odd behaviour of 1-bromo-2-phenylethene must be intimately connected with its electron distribution, which is being investigated by core electron spectroscopy and theoretical methods. ${ }^{18}$

Ring opening. Trihalides 1 were allowed to react at room temperature with $50 \%$ aqueous sodium hydroxide ( 8 equiv.) in the presence of ethanol (4 equiv.), a small amount of TEBA and some dichloromethane, conditions which are termed phase-transfer conditions or PTC throughout. It appeared that the course of reaction was fairly sensitive to the cyclopropane structure. Two of the compounds, 1,1,2-tribromo-3,3-dimethylcyclopropane (1q) and 1,1-dibromo-2-chloro-3,3-dimethylcyclopropane (1r), were completely unreactive and were recovered almost quantitatively even after stirring at elevated temperatures for an extended period of time. The other trihalocyclopropanes, on the other hand, did react, albeit slowly unless the reaction mixture was stirred very well, and underwent ring opening to afford, in most cases, mixtures of acetylenic ethyl ketals (2) and acetylenic ethyl acetals (3) were formed in fair to excellent yields. The results are summarized in Table 2.

The data in Table 2 show several notable features. Thus, the larger the number of chlorine atoms attached

Table 2. Acetylenic ethyl ketals (2) and acetals (3) obtained by reacting 1,1,2-trihalocyclopropanes (1) $(10 \mathrm{mmol})$ with $50 \%$ aqueous sodium hydroxide in the presence of ethanol $(40 \mathrm{mmol})$, dichloromethane, and triethylbenzylammonium chloride (TEBA).

\begin{tabular}{|c|c|c|c|}
\hline Starting material & Products & $2: 3$ & Total yield $(\%)^{a}$ \\
\hline $1 a$ & $2 a$ & $b$ & 70 \\
\hline $1 \mathrm{~b}$ & $2 a$ & $b$ & 57 \\
\hline 1c & $2 b+3 b$ & 1.0 & 80 \\
\hline 1d & $2 b+3 b^{c}$ & $>9$ & 50 \\
\hline $1 e$ & $2 b+3 b$ & 1.0 & 64 \\
\hline $1 f$ & $2 b+3 b^{c}$ & $>20$ & 40 \\
\hline $1 \mathrm{~g}$ & $2 c+3 c^{c}$ & 1.0 & 50 \\
\hline $1 \mathrm{~h}$ & $2 c+3 c^{c}$ & 4.0 & 22 \\
\hline $1 i^{d}$ & $2 b+3 b$ & 1.0 & 80 \\
\hline $1 \mathrm{j}^{d}$ & $2 b+3 b^{c}$ & $>30$ & 30 \\
\hline $\mathbf{1 k}^{d}$ & $2 b+3 b$ & 1.5 & 57 \\
\hline $11^{d}$ & $2 b+3 b^{c}$ & $>40$ & 39 \\
\hline $1 \mathrm{~m}^{d}$ & $2 d$ & $e$ & 80 \\
\hline $1 \mathrm{n}^{d}$ & 2d & $e$ & 64 \\
\hline $10^{d}$ & $2 d$ & e & 51 \\
\hline $1 \mathrm{p}^{d, f}$ & $2 d$ & $e$ & 44 \\
\hline
\end{tabular}

${ }^{a}$ Total isolated yield of the acetal(s). ${ }^{b} \mathbf{2 a}$ and $\mathbf{3 a}$ are identical. ${ }^{c}$ In addition an $\alpha, \beta$-unsaturated aldehyde and several minor products were obtained, see text. ${ }^{d}$ Mixture of the trans and cis isomers. ${ }^{\theta} \mathbf{2 d}$ and $\mathbf{3 d}$ are identical. ${ }^{f}$ The compound reacted very sluggishly and the reaction was terminated when $95 \%$ had been consumed as shown by gas chromatography.

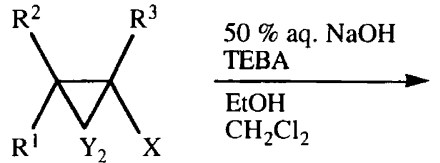

Scheme 2

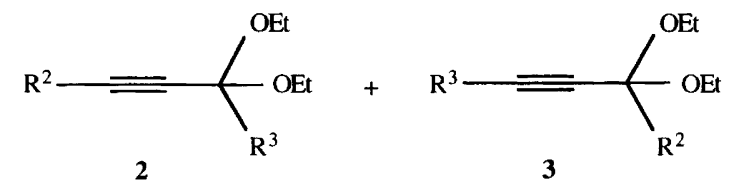

3 
to the ring, the lower the acetal yield. This is nicely reflected in the results obtained by reacting the $\mathbf{1 c}-\mathbf{1 f}$ series of 1,1,2-trihalo-2-methylcyclopropanes under PTC; the total yield of acetylenic products drops $10-15 \%$ for each bromine atom that is replaced by chlorine. In a similar fashion the yield of 3,3-diethoxy-1-propyne (2a) dropped from 70 to $57 \%$ when the starting material was changed from 1,1,2-tribromocyclopropane (1a) to 1,1-dichloro-2-bromocyclopropane (1b). It is also noteworthy that when a ketal and an acetal are formed, the isomer composition is halogen dependent. Thus, when 1,1,2-tribromo-2-methylcyclopropane (1c) is allowed to react under phase-transfer conditions 3,3-diethoxy-1butyne (2b) and 1,1-diethoxy-2-butyne (3b) are formed in a $1: 1$ ratio, in contrast to the behaviour of 1,1,2-trichloro-2-methylcyclopropane (1f) which, under the same conditions, gives almost exclusively ketal $\mathbf{2 b}$.

The fact that 1,1,2-trihalocyclopropane 4 (Scheme 3) afforded acetylenic ethyl acetals and ketals when subjected to phase-transfer conditions requires that the reaction consists of several steps including ring opening, dehydrohalogenation and formal substitution of halogen atoms by ethoxy groups. Since no reaction took place in the absence of ethanol, ethoxide is presumably the active base. Furthermore, since $\mathbf{1 q}$ and $\mathbf{1 r}$ are completely unreactive under the reaction conditions it is reasonable to believe that the ring opening is initiated by abstraction of a hydrogen from C-3 and expulsion of one of the

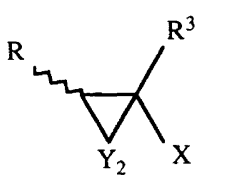

4<smiles></smiles>

6<smiles>[Y][V]</smiles>

$\mathbf{R}$

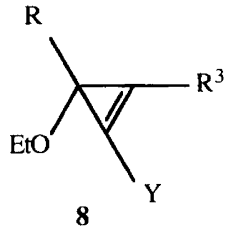

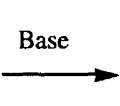

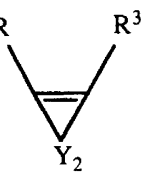

5
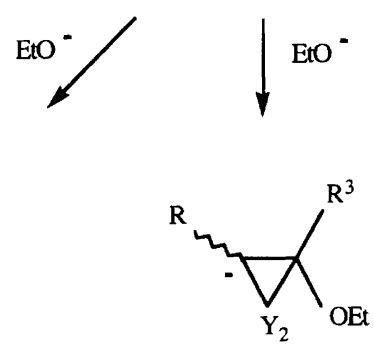

7
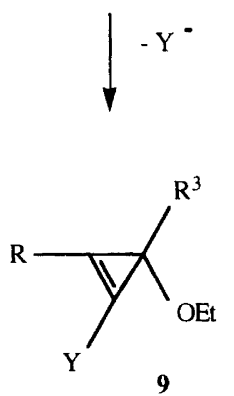

Scheme 3 halogen atoms. In addition, since only one product is obtained when $R=R^{1}$ and the same product mixture is formed when, for instance, $\mathbf{1 c}$ and $\mathbf{1 i}$ are reacted, the halogen atom at $\mathrm{C}-2$ must be expelled, resulting in formation of the corresponding 3,3-dihalocyclopropene (5). The ease with which the alkene formation takes place is expected to be influenced by the electronic and leaving-group properties of chlorine and bromine, and this is indeed observed. Cyclopropenes like $\mathbf{5}$ are known to react with nucleophiles ${ }^{19-22}$ and are attacked by ethoxide at both ends of the carbon-carbon double bond. The resulting cyclopropyl anions (6 and 7) are unstable and collapse to cyclopropenes $\mathbf{8}$ and $\mathbf{9}$, which are reactive and are attacked by ethoxide to provide $\mathbf{2}$ and $\mathbf{3}$, respectively. ${ }^{19,23-26}$

Under PTC it might be envisaged that anions 6 and 7 abstract a proton and are converted into the corresponding 2-ethoxy-1,1-dihalocyclopropanes derivatives prior to formation of cyclopropenes $\mathbf{8}$ and $\mathbf{9}$. However, this possibility has been ruled out by experiment. Thus, when 1,1-dibromo-2-ethoxy-3-methylcyclopropane, one of the two possible derivatives from reaction with 1c, was subjected to phase-transfer conditions, $\mathbf{2 b}$ and $\mathbf{3 b}$ were not obtained; the only product isolated was 2-bromo-1,1-diethoxy-2-butene (10) (Scheme 4) which was hydrolyzed under acidic condition to 2-bromo-2butenal. Interestingly, acetal $\mathbf{1 0}$ was formed as a single isomer, which was assigned the $Z$ configuration on the basis of NOE experiments. The assignment was supported by converting $\mathbf{1 0}$ to the corresponding aldehyde, 2-bromo-2-butenal; the proton NMR spectrum of this compound (signals at $2.15,7.26$ and $9.22 \mathrm{ppm}$ ) was almost identical to that exhibited by 2 -chloro-2Z-butenal (signals at 2.10, 7.13 and $9.40 \mathrm{ppm}$ ). ${ }^{27}$

A noteworthy feature of the ring opening of the 1,1,2-trihalocyclopropanes is the partial deviation from the main reaction course when $1 \mathbf{d}, \mathbf{1 f}-\mathbf{1 h}, \mathbf{1 j}$ and $\mathbf{1 l}$ are reacted under PTC. Although a mixture of an acetylenic ethyl acetal and an acetylenic ethyl ketal constitutes the main product from these cyclopropanes as well, significant amounts $(>10 \%)$ of an $\alpha, \beta$-unsaturated aldehyde and minor amounts of at least three other products (total yield $<5 \%$ ) were also obtained. The aldehydes were isolated by flash chromatography, and based on spectroscopic data their structures were elucidated to be 3-ethoxy-2-methyl-2-propenal (11a) (from 1d, 1f, 1j and 11) and 3-ethoxy-2-phenyl-2-propenal (11b) (from 1g and 1h). This conclusion was supported by conversion of $11 \mathrm{a}$ and 11b into 4-methylisoxazole and 4-phenylisoxazole, respectively, upon treatment with hydroxylamine. The
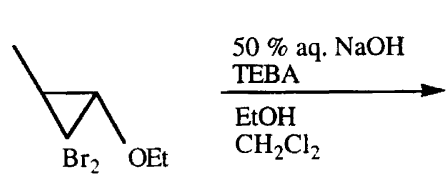

Scheme 4 
proton and carbon NMR spectra of both aldehydes showed in essence one set of peaks, a clear indication that both compounds were formed almost exclusively as a single isomer, but so far we have not been able to determine their stereochemistry.

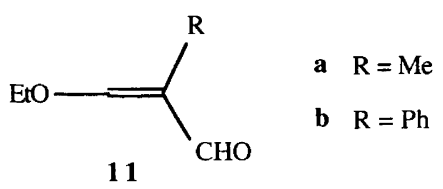

Aldehydes similar to 11a and 11b have been obtained from other halogenated cyclopropanes under similar conditions $^{28}$ by a reaction sequence involving a cyclopropene-vinylcarbene rearrangement. ${ }^{2,19,29-33}$ Such a rearrangement may very well occur in our cases as well and convert cyclopropene 12 into vinyl carbene 13, which affords 11 by reaction with water (Scheme 5 ). The alternative rearrangement $(12 \rightarrow 14)$, which has literature precedence, ${ }^{3,} 24$ would not give 11 without another deepseated and unprecedented rearrangement. It should also be noted that experiments carried out to trap the postulated carbene intermediate by performing ring opening of various 1,1,2-trihalocyclopropanes in the presence of a reactive alkene ${ }^{2,}{ }^{34-37}$ failed. However, unsuccessful trapping of similar vinyl carbenes has been reported, a fact which suggests that intermediate $\mathbf{1 3}$ has a short lifetime under phase-transfer conditions.

\section{Experimental}

General. IR spectra were recorded on a Shimadzu IR-435 spectrophotometer with the compounds as liquid films unless stated otherwise. ${ }^{1} \mathrm{H}$ NMR spectra were run on Jeol FX 90Q (89.55 MHz), Varian Gemini (200 MHz), and Jeol JNM-EX $400(400 \mathrm{MHz})$ spectrometers, and ${ }^{13} \mathrm{C}$ NMR spectra were obtained on the instruments at $22.50,50$ and $100 \mathrm{MHz}$, respectively. $\mathrm{CDCl}_{3}$ was used as solvent, and tetramethylsilane (TMS) was added as

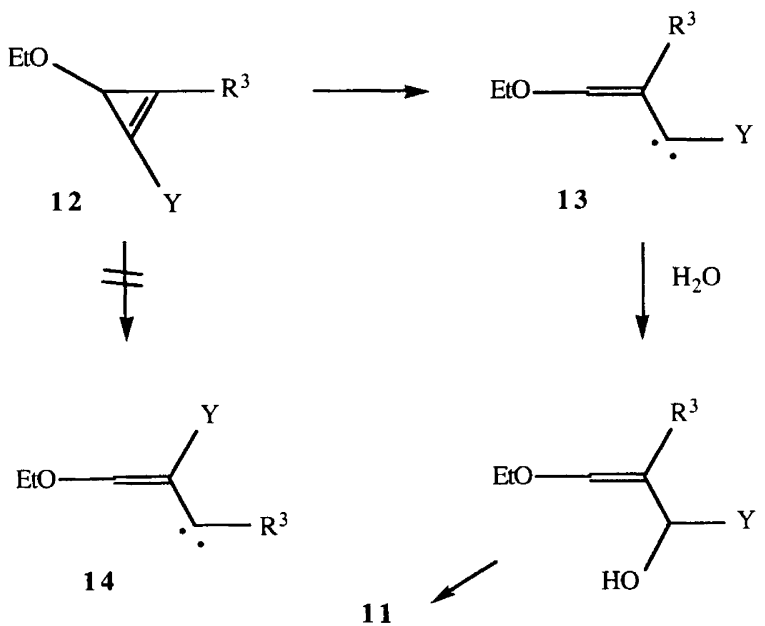

Scheme 5 internal reference. Chemical shifts are reported in ppm downfield from TMS. GC analyses were performed either on a Carlo Erba HRGC 5300 Mega Series gas chromatograph equipped with FID and a Chrompack CP-Sil 5CB fused silica column $(26 \mathrm{~m} \times 0.32 \mathrm{~mm}$ i.d. $)$ and connected to an LDC/Milton Roy CI-10B integrator or on a Varian 3700 gas chromatograph equipped with a TCD and a Carbo-wax 20M or an OV-17 column and attached to a Varian 9176 recorder. No corrections were made for response ratios. Mass spectra were obtained on a VG $7070 \mathrm{H}$ Micromass spectrometer operated in the EI mode at $70 \mathrm{eV}$. The spectra are reported as $m / z$ (\% rel. int.). All haloalkenes were commercially available.

Preparation of gem-dihalocyclopropanes. Most of the compounds were synthesized from the corresponding alkene on a $50 \mathrm{mmol}$ scale under phase-transfer conditions in the absence of ethanol. ${ }^{8}$ The preparations of $\mathbf{1 a}$, 1b and cis/trans-1,1-dibromo-2-ethoxy-3-methylcyclopropane were performed at $0{ }^{\circ} \mathrm{C}$ (ice-water bath), whereas the other compounds were prepared at room temperature. The yields are summarized in Table 1.

1,1,2-Tribromocyclopropane (1a), from vinyl bromide, b.p. $78^{\circ} \mathrm{C} / 30 \mathrm{mmHg}$. IR: 3080 (w), 3050 (w), 1415 (m), $1265(\mathrm{w}), 1200(\mathrm{w}), 1096(\mathrm{~m}), 1053(\mathrm{~m}), 1022(\mathrm{~m}), 910$ (w), 876 (w), 668 (s), $605 \quad(\mathrm{~m}) \mathrm{cm}^{-1} ;{ }^{1} \mathrm{H}$ NMR (400 MHz): $\delta 1.73$ (1 H, dd, $J 6.35$ and $9.28 \mathrm{~Hz}$ ), 2.24 $(1 \mathrm{H}, \mathrm{t}, J 9.28 \mathrm{~Hz}), 3.59(1 \mathrm{H}$, dd, $J 6.35$ and $9.28 \mathrm{~Hz})$; ${ }^{13} \mathrm{C}$ NMR (100 MHz): $\delta 24.4\left(\mathrm{CBr}_{2}\right), 29.1(\mathrm{CHBr}), 32.4$ $\left(\mathrm{CH}_{2}\right)$; MS: $282\left(0.4, M^{+}\right), 281\left(0.4, M^{+}\right), 280(1.4$, $\left.M^{+}\right), 279\left(0.9, M^{+}\right), 278\left(1.8, M^{+}\right), 277\left(0.8, M^{+}\right), 276$ $\left(0.3, M^{+}\right), 275(0.2), 202(7), 201$ (91), $200(14), 199$ (100), 198 (8), 197 (94), 175 (12), 174 (3), 173 (26), $172(6), 171(13), 170(3), 162$ (1.5), $160(3), 158$ (1.5), 120 (16), 119 (68), 118 (20), 117 (71), 93 (20), 81 (20), 79 (21). The product was contaminated with a by-product, tetrabromomethane, which gave rise to a peak at $-29.7 \mathrm{ppm}$ in the ${ }^{13} \mathrm{C}$ NMR spectrum of $\mathbf{1 a}$. The compound was formed in ca. $5 \%$ yield as judged from the gas chromatogram of the reaction mixture.

1-Bromo-2,2-dichlorocyclopropane (1b), from vinyl bromide, b.p. $40^{\circ} \mathrm{C} / 28 \mathrm{mmHg}$. IR: 3080 (w), 3050 (w), 1415 (m), $1272(\mathrm{w}), 1210(\mathrm{~m}), 1102$ (s), 1057 (m), 1035 (m), $920(\mathrm{w}), 890(\mathrm{w}), 755$ (s), $615(\mathrm{~s}) \mathrm{cm}^{-1} ;{ }^{1} \mathrm{H}$ NMR (400 MHz): $\delta 1.65(1 \mathrm{H}$, dd, $J 6.84$ and $8.79 \mathrm{~Hz}), 2.13$ $(1 \mathrm{H}, \mathrm{t}, J 8.79 \mathrm{~Hz}), 3.52(1 \mathrm{H}, \mathrm{dd}, J 6.84$ and $9.28 \mathrm{~Hz})$; ${ }^{13} \mathrm{C}$ NMR (100 MHz): $\delta 28.7(\mathrm{CHBr}), 30.8\left(\mathrm{CH}_{2}\right)$, $58.0\left(\mathrm{CCl}_{2}\right)$.

1,1,2-Tribromo-2-methylcyclopropane (1c), from 2bromopropene, b.p. $78^{\circ} \mathrm{C} / 18 \mathrm{mmHg}$ (lit. ${ }^{4}$ b.p. $\left.89-90{ }^{\circ} \mathrm{C} / 14 \mathrm{mmHg}\right) .{ }^{13} \mathrm{C}$ NMR (100 MHz): $\delta 29.8$ $\left(\mathrm{CH}_{3}\right), 33.2\left(\mathrm{CBr}_{2}\right), 38.4\left(\mathrm{CH}_{2}\right), 39.6\left[C\left(\mathrm{CH}_{3}\right) \mathrm{Br}\right]$; IR and ${ }^{1} \mathrm{H}$ NMR spectra. ${ }^{4}$

1-Bromo-2,2-dichloro-1-methylcyclopropane (1d), from 2-bromopropene, b.p. $40^{\circ} \mathrm{C} / 16 \mathrm{mmHg}$ (lit. ${ }^{4}$ b.p. 
$\left.45-46{ }^{\circ} \mathrm{C} / 16 \mathrm{mmHg}\right) .{ }^{13} \mathrm{C}$ NMR (100 MHz): $\delta 27.5$ $\left(\mathrm{CH}_{3}\right), 36.5\left(\mathrm{CH}_{2}\right), 39.6\left[\mathrm{C}\left(\mathrm{CH}_{3}\right) \mathrm{Br}\right], 63.7\left(\mathrm{CCl}_{2}\right)$; IR and ${ }^{1} \mathrm{H}$ NMR spectra. ${ }^{4}$

1,1-Dibromo-2-chloro-2-methylcyclopropane (1e), from 2-chloropropene, b.p. $58^{\circ} \mathrm{C} / 18 \mathrm{mmHg}$ (lit. ${ }^{23}$ b.p. 35-38 ${ }^{\circ} \mathrm{C} / 0.6 \mathrm{mmHg}$ ). IR: $3180(\mathrm{w}), 2995$ (w), $2860(\mathrm{w})$, $1440(\mathrm{~m}), 1418(\mathrm{~m}), 1380(\mathrm{~m}), 1295(\mathrm{w}), 1158(\mathrm{~m}), 1087$ (m), 1038 (m), 1017 (s), $837(\mathrm{w}), 698(\mathrm{~s}), 670(\mathrm{~m}), 600$ (s) $\mathrm{cm}^{-1} ;{ }^{1} \mathrm{H}$ NMR $(400 \mathrm{MHz}): \delta 1.88(1 \mathrm{H}, \mathrm{d}, J$ $9.27 \mathrm{~Hz}), 1.94$ (3 H, s), $1.99(1 \mathrm{H}, \mathrm{d}, J 9.27 \mathrm{~Hz})$; ${ }^{13} \mathrm{C}$ NMR ( $\left.100 \mathrm{MHz}\right): \delta 27.3\left(\mathrm{CH}_{3}\right), 33.5\left(\mathrm{CBr}_{2}\right), 37.6$ $\left(\mathrm{CH}_{2}\right), 48.4\left[\mathrm{C}\left(\mathrm{CH}_{3}\right) \mathrm{Cl}\right]$.

1,1,2-Trichloro-2-methylcyclopropane (1f), from 2-chloropropene, b.p. $70{ }^{\circ} \mathrm{C} / 100 \mathrm{mmHg}$ (lit. ${ }^{4}$ b.p. $\left.85-86^{\circ} \mathrm{C} / 17 \mathrm{mmHg}\right)$. The compound foamed excessively during distillation. ${ }^{13} \mathrm{C}$ NMR $(100 \mathrm{MHz}): \delta 25.2\left(\mathrm{CH}_{3}\right)$, $35.5\left(\mathrm{CH}_{2}\right), 48.8\left(\mathrm{CCl}_{2}\right), 63.9\left[\mathrm{C}\left(\mathrm{CH}_{3}\right) \mathrm{Cl}\right] ; \mathrm{IR}$ and ${ }^{1} \mathrm{H}$ NMR spectra. ${ }^{4}$

1,1,2-Tribromo-2-phenylcyclopropane (1g), from 1bromo-1-phenylethene. The compound was isolated by flash chromatography (silica gel, pentane) and subsequently recrystallized from hexane, m.p. $88-89^{\circ} \mathrm{C}$. IR $\left(\mathrm{CCl}_{4}\right): 3160(\mathrm{w}), 3060$ (w), 2998 (w), 1675 (w), 1595 (w), $1576(\mathrm{w}), 1492(\mathrm{w}), 1445(\mathrm{~m}), 1415(\mathrm{~m}), 1065$ (m), $1055(\mathrm{w}), 990(\mathrm{~m}), 755(\mathrm{~s}), 696(\mathrm{~s}), 618(\mathrm{~s}), 575(\mathrm{w}) \mathrm{cm}^{-1}$; ${ }^{1} \mathrm{H}$ NMR (400 MHz): $\delta 2.24(1 \mathrm{H}, \mathrm{d}, J 9.28 \mathrm{~Hz}), 2.50$ $(1 \mathrm{H}, \mathrm{d}, J 9.28 \mathrm{~Hz}), 7.20-7.48(5 \mathrm{H}, \mathrm{m}) ;{ }^{13} \mathrm{C}$ NMR $(100 \mathrm{MHz}): \delta 31.8\left(\mathrm{CBr}_{2}\right), 37.1\left(\mathrm{CH}_{2}\right), 42.9(\mathrm{CPhBr})$, $128.6(2 \times \mathrm{CH}), 128.9(\mathrm{CH}), 129.1(2 \times \mathrm{CH}), 140.0(\mathrm{C})$.

2-Bromo-1,1-dichloro-2-phenylcyclopropane (1h), from 1-bromo-1-phenylethene. The compound was isolated by flash chromatography (silica gel, pentane) and subsequently recrystallized from hexane, m.p. $44-46^{\circ} \mathrm{C}$. IR $\left(\mathrm{CCl}_{4}\right): 3070(\mathrm{~m}), 3045(\mathrm{~m}), 3015(\mathrm{~m}), 1580(\mathrm{w}), 1485$ (m), $1437(\mathrm{~m}), 1400(\mathrm{~m}), 1302(\mathrm{w}), 1180(\mathrm{~m}), 1053$ (s), $994(\mathrm{~s}), 945$ (m), $910(\mathrm{~m}), 988$ (s), 630 (s); ${ }^{1} \mathrm{H}$ NMR (400 MHz): $\delta 2.13(1 \mathrm{H}, \mathrm{d}, J 9.28 \mathrm{~Hz}), 2.36(1 \mathrm{H}, \mathrm{d}, J$ $9.28 \mathrm{~Hz}), 7.30-7.50(5 \mathrm{H}, \mathrm{m}) ;{ }^{13} \mathrm{C}$ NMR $(50 \mathrm{MHz}): \delta$ $35.2\left(\mathrm{CH}_{2}\right), 42.9(\mathrm{CPhBr}), 62.7\left(\mathrm{CCl}_{2}\right), 128.5(2 \times \mathrm{CH})$, $128.8(\mathrm{CH}), 129.0(2 \times \mathrm{CH}), 138.6(\mathrm{C})$.

cis/trans-1,1,2-Tribromo-3-methylcyclopropane (1i), from a mixture of $E$ - and $Z$-1-bromopropene, b.p. $88-90{ }^{\circ} \mathrm{C} / 16 \mathrm{mmHg}$ (lit. ${ }^{4} 86^{\circ} \mathrm{C} / 8.5 \mathrm{mmHg}$ for the trans isomer). The IR spectrum of the mixture is essentially identical to that of the trans isomer. ${ }^{4}$ The ${ }^{1} \mathrm{H}$ NMR spectrum of one isomer has been reported. ${ }^{4}$ For the mixture: ${ }^{1} \mathrm{H}$ NMR (400 MHz): $\delta 1.24$ and $1.36(3 \mathrm{H}$, two $\mathrm{d}$ in a $3.7: 1$ ratio, $J 6.35 \mathrm{~Hz}$ for both isomers), 1.69 and $1.87(1 \mathrm{H}$, two $\mathrm{m}$ in a $1: 3.7$ ratio), 3.15 and 3.76 ( 1 $\mathrm{H}$, two $\mathrm{d}$ in a $1: 3.7$ ratio, $J 6.84$ and $9.76 \mathrm{~Hz}$, respectively); ${ }^{13} \mathrm{C}$ NMR (100 MHz): $\delta 14.3\left(\mathrm{CH}_{3}\right.$, major), 16.4 ( $\mathrm{CH}_{3}$, minor), 30.0 (major), 33.8 (major), 34.7 (minor), 35.4 (minor), 36.1 (minor), 37.1 (major).
cis/trans-1-Bromo-2,2-dichloro-3-methylcyclopropane (1j), from a mixture of $E$ - and Z-1-bromopropene, b.p. $44-46^{\circ} \mathrm{C} / 18 \mathrm{mmHg}$. IR: $3110(\mathrm{~m}), 2960$ (m), 2870 $(\mathrm{m}), 2750(\mathrm{w}), 1445(\mathrm{~m}), 1383(\mathrm{~m}), 1365(\mathrm{w}), 1252(\mathrm{~s})$, $1215(\mathrm{~m}), 1200(\mathrm{~m}), 1132$ (s), 1048 (s), 1020 (s), $993(\mathrm{~m})$, $885(\mathrm{~s}), 825(\mathrm{~s}), 772(\mathrm{~s}), 700(\mathrm{~m}), 678(\mathrm{~m}) \mathrm{cm}^{-1} ;{ }^{1} \mathrm{H}$ NMR $(400 \mathrm{MHz}): \delta 1.25$ and $1.36(3 \mathrm{H}$, two $\mathrm{d}$ in a $3.2: 1$ ratio, $J 6.34 \mathrm{~Hz}$ for both isomers), 1.76 and $1.88(1 \mathrm{H}$, two $\mathrm{m}$ in a $1: 3.2$ ratio), 3.08 and $3.64(1 \mathrm{H}$, two $\mathrm{d}$ in a $1: 3.2$ ratio, $J 6.84$ and $9.76 \mathrm{~Hz}$, respectively); ${ }^{13} \mathrm{C}$ NMR (100 MHz): $\delta 11.8\left(\mathrm{CH}_{3}\right.$, major), $13.9\left(\mathrm{CH}_{3}\right.$, minor $), 29.2$ (major), 34.1 (minor), 35.3 (minor), 35.9 (major), 62.6 $\left(\mathrm{CCl}_{2}\right.$, major $), 63.7\left(\mathrm{CCl}_{2}\right.$, minor $)$.

cis/trans-1,1-Dibromo-2-chloro-3-methylcyclopropane (1k), from a mixture of $E$ - and Z-1-chloropropene, b.p. $60-62{ }^{\circ} \mathrm{C} / 20 \mathrm{mmHg}$. IR: 3110 (w), 2960 (m), 2870 (m), 2740 (w), 1445 (m), 1380 (m), 1269 (m), 1128 (m), 1042 (s), 1023 (w), $995(\mathrm{~m}), 882$ (s), 832 (s), $812(\mathrm{~m})$, $772(\mathrm{~m}), 742(\mathrm{~s}), 720(\mathrm{~m}), 668(\mathrm{~s}) \mathrm{cm}^{-1}$; ${ }^{1} \mathrm{H}$ NMR $(400 \mathrm{MHz}): \delta 1.23$ and $1.35(3 \mathrm{H}$, two $\mathrm{d}$ in a $1.05: 1$ ratio, $J 6.35 \mathrm{~Hz}$ for both isomers), 1.69 and $1.95(1 \mathrm{H}$, two $\mathrm{m}$ in a $1: 1.05$ ratio), 3.13 and $3.69(1 \mathrm{H}$, two $\mathrm{d}$ in a $1: 1.05$ ratio, $J 6.35$ and $9.28 \mathrm{~Hz}$, respectively); ${ }^{13} \mathrm{C}$ NMR (100 MHz): $\delta 12.0\left(\mathrm{CH}_{3}\right), 16.1\left(\mathrm{CH}_{3}\right), 30.3,34.4,35.4$, $35.7,45.3,46.6$.

cis/trans-1,1,2-Trichloro-3-methylcyclopropane (11), from a mixture of $E$ - and $Z$-1-chloropropene b.p. $74-76^{\circ} \mathrm{C} /$ $100 \mathrm{mmHg}$. Excessive foaming is observed during distillation. IR: 3100 (m), 2980 (s), 2870 (s), 2750 (m), 1450 (s), $1382(\mathrm{~m}), 1275(\mathrm{~m}), 1260(\mathrm{~m}), 1205(\mathrm{~m}), 1135(\mathrm{~s}), 1100$ (m), 1055 (s), 1030 (m), 998 (s), 805 (s), 748 (s), 730 (m), 715 (s), 705 (s), 660 (s), $625(\mathrm{~m}) \mathrm{cm}^{-1} ;{ }^{1} \mathrm{H}$ NMR (400 MHz): $\delta 1.23$ and $1.35(3 \mathrm{H}$, two $\mathrm{d}$ in a $1: 2.1$ ratio, $J 6.4 \mathrm{~Hz}$ for both isomers), 1.74 and $1.94(1 \mathrm{H}$, two $\mathrm{m}$ in a 2.1:1 ratio), 3.09 and $3.61(1 \mathrm{H}$, two $\mathrm{d}$ in a $2.1: 1$ ratio, $J 5.9$ and $9.3 \mathrm{~Hz}$, respectively); ${ }^{13} \mathrm{C}$ NMR (100 MHz): $\delta 9.5\left(\mathrm{CH}_{3}\right.$, minor), $13.5\left(\mathrm{CH}_{3}\right.$, major $), 29.5$ (minor), 34.9 (major), 44.5 (major), 45.8 (minor), 62.9 $\left(\mathrm{CCl}_{2}\right.$, minor $), 64.2\left(\mathrm{CCl}_{2}\right.$, major $)$.

cis/trans-1,1,2-Tribromo-2,3-dimethylcyclopropane (1m), from a mixture of $E$ - and Z-2-bromo-2-butene, b.p. $90-92^{\circ} \mathrm{C} / 18 \mathrm{mmHg}$. IR: 2980 (m), 2930 (m), 2850 (w), $1445(\mathrm{~m}), 1380(\mathrm{~m}), 1140(\mathrm{w}), 1120(\mathrm{~m}), 1083(\mathrm{w})$, 994 (m), 952 (w), 761 (s) $\mathrm{cm}^{-1}$; ${ }^{1} \mathrm{H}$ NMR (400 MHz): $\delta$ 1.22 and $1.32(3 \mathrm{H}$, two $\mathrm{d}$ in a $1: 6.5$ ratio, $J 6.4 \mathrm{~Hz}$ for both isomers), 1.39 and $1.95(1 \mathrm{H}$, two $\mathrm{q}$ in a $6.5: 1$ ratio, $J 6.4 \mathrm{~Hz}$ for both isomers), 1.87 and $2.11(3 \mathrm{H}$, two $\mathrm{s}$ in a $1: 6.5$ ratio); ${ }^{13} \mathrm{C}$ NMR $(100 \mathrm{MHz}): \delta 12.0$ (minor isomer), 16.2 (major isomer), 24.0 (minor isomer), 31.2 (major isomer), 36.4 (major isomer), 38.7 (minor isomer), 42.7 (major isomer), 47.7 (major isomer), two carbon atoms of the minor isomer give rise to peaks that overlap with two of the peaks due to the major isomer. 
cis/trans-1-Bromo-2,2-dichloro-1,3-dimethylcyclopropane $(1 n)$, from a mixture of $E$ - and $Z$-2-bromo-2-butene, b.p. $58-60{ }^{\circ} \mathrm{C} / 20 \mathrm{mmHg}$. IR: 2980 (m), 2940 (m), 2870 $(\mathrm{w}), 1443(\mathrm{~m}), 1380(\mathrm{~m}), 1250(\mathrm{w}), 1148(\mathrm{w}), 1122(\mathrm{~m})$, $1090(\mathrm{w}), 993(\mathrm{~s}), 968(\mathrm{~m}), 832(\mathrm{~s}), 800(\mathrm{~m}), 690(\mathrm{w}) \mathrm{cm}^{-1}$; ${ }^{1} \mathrm{H}$ NMR (400 MHz): $\delta 1.22$ and $1.31(3 \mathrm{H}$, two d in a $1: 6.6$ ratio, $J 6.8$ and $6.4 \mathrm{~Hz}$, respectively), 1.41 and 1.95 $(1 \mathrm{H}$, two q in a $6.6: 1$ ratio, $J 6.4$ and $6.8 \mathrm{~Hz}$, respectively), 1.82 and $2.04(3 \mathrm{H}$, two $\mathrm{s}$ in a $1: 6.5$ ratio); ${ }^{13} \mathrm{C}$ NMR (100 MHz): $\delta 9.5$ (minor isomer), 13.7 (major isomer), 21.7 (minor isomer), 28.6 (major isomer), 35.3 (major isomer), 37.6 (minor isomer), 42.3 (minor isomer), 47.4 (major isomer), $68.3\left(\mathrm{CCl}_{2}\right.$ for both isomers).

cis/trans-1,1-Dibromo-2-chloro-2,3-dimethylcyclopropane (10), from a mixture of $E$ - and $Z$-2-chlor-2-butene, b.p. $78-80^{\circ} \mathrm{C} / 18 \mathrm{mmHg}$. IR: $2980(\mathrm{~m}), 2930$ (m), 2870 (w), $1445(\mathrm{~m}), 1380(\mathrm{~m}), 1253(\mathrm{w}), 1148(\mathrm{w}), 1152(\mathrm{~m})$, $1122(\mathrm{~m}), 1118(\mathrm{~m}), 1085(\mathrm{~m}), 1075(\mathrm{~m}), 988(\mathrm{~s}), 952$ $(\mathrm{m}), 860(\mathrm{~m}), 815(\mathrm{~m}), 768 \quad(\mathrm{~s}) \mathrm{cm}^{-1} ;{ }^{1} \mathrm{H}$ NMR $(400 \mathrm{MHz}): \delta 1.22$ and $1.29(3 \mathrm{H}$, two $\mathrm{d}$ in a $1: 2$ ratio, $J 6.8$ and $6.4 \mathrm{~Hz}$, respectively), 1.61 and 1.92 ( $1 \mathrm{H}$, two q in a $2: 1$ ratio, $J 6.4$ and $6.8 \mathrm{~Hz}$, respectively), 1.72 and 1.94 (3 H, two s in a $1: 2 \mathrm{ratio}) ;{ }^{13} \mathrm{C}$ NMR (100 MHz): $\delta 12.2$ (minor isomer), 13.6 (major isomer), 21.8 (minor isomer), 28.6 (major isomer), 36.1 (major isomer), 38.0 (minor isomer), 42.8 (major isomer), 42.9 (minor isomer), 50.7 (minor isomer), 52.7 (major isomer).

cis/trans-1,1,2-Trichloro-2,3-dimethylcyclopropane (1p), from a mixture of $E$ - and $Z$-2-chloro-2-butene, b.p. $44-46^{\circ} \mathrm{C} / 18 \mathrm{mmHg}$. Extreme foaming is observed during the distillation. IR: $2980(\mathrm{~m}), 2930(\mathrm{~m}), 2870(\mathrm{w}), 1446$ (m), $1380(\mathrm{~m}), 1255(\mathrm{w}), 1158(\mathrm{~m}), 1122(\mathrm{~m}), 1090(\mathrm{w})$, $1078(\mathrm{~m}), 995(\mathrm{~s}), 968(\mathrm{~m}), 842(\mathrm{~s}), 798(\mathrm{~m}), 620$ (m) $\mathrm{cm}^{-1} ;{ }^{1} \mathrm{H}$ NMR (400 MHz): $\delta 1.22$ and $1.31(3 \mathrm{H}$, two $\mathrm{d}$ in a $1: 2$ ratio, $J 6.4 \mathrm{~Hz}$ for both isomers), 1.58 and $1.88(1 \mathrm{H}$, two q in a $2: 1$ ratio, $J 6.4 \mathrm{~Hz}$ for both isomers), 1.67 and $1.88(3 \mathrm{H}$, two $\mathrm{s}$ in a $1: 2$ ratio); ${ }^{13} \mathrm{C} \mathrm{NMR}$ (100 MHz): $\delta 9.7$ (minor isomer), 10.1 (major isomer), 19.7 (minor isomer), 26.3 (major isomer), 34.9 (major isomer), 36.7 (minor isomer), 50.8 (minor isomer), 52.8 (major isomer), 68.3 (major isomer), 68.6 (minor isomer).

1,1,2-Tribromo-3,3-dimethylcyclopropane (1q), from 1-bromo-2-methylpropene, b.p. $90-92{ }^{\circ} \mathrm{C} / 22 \mathrm{mmHg}$. The compound has been prepared by Baird, ${ }^{2}$ but no data are given. IR: $3060(\mathrm{w}), 2980(\mathrm{~m}), 2930(\mathrm{~m}), 2850(\mathrm{w}), 2730$ (w), $1450(\mathrm{~m}), 1373(\mathrm{~m}), 1245(\mathrm{~s}), 1200(\mathrm{w}), 1110(\mathrm{w})$, $1095(\mathrm{~m}), 1015$ (w), $1000(\mathrm{~s}), 958(\mathrm{w}), 837$ (m), $784(\mathrm{~s})$, $712(\mathrm{~m}), 693$ (s), $658(\mathrm{w}) \mathrm{cm}^{-1} ;{ }^{1} \mathrm{H}$ NMR $(400 \mathrm{MHz}): \delta$ 1.37 (3 H, s), 1.51 (3 H, s), 3.47 (1 H, s); ${ }^{13} \mathrm{C}$ NMR (100 MHz): $\delta 22.7\left(\mathrm{CH}_{3}\right), 25.6\left(\mathrm{CH}_{3}\right), 30.6,42.6,43.0$.

1,1-Dibromo-2-chloro-3,3-dimethylcyclopropane

(1r), from 1-chloro-2-methylpropene, b.p. $74-76^{\circ} \mathrm{C} / 25 \mathrm{mmHg}$. IR: 3060 (m), 2980 (s), 2930 (s), 2850 (s), 2730 (m), 1453 (s), 1440 (s), 1390 (m), 1373 (s), 1335 (w), 1260 (s), 1218 (m), $1140(\mathrm{~m}), 1095(\mathrm{~s}), 1018(\mathrm{~m}), 1005(\mathrm{~s}), 958(\mathrm{~m}), 862$ (s), 794 (s), 740 (s), 710 (w), 669 (s) $\mathrm{cm}^{-1} ;{ }^{1} \mathrm{H}$ NMR (400 MHz): $\delta 1.34$ (3 H, s), 1.47 (3 H, s), 3.37 (1 H, s); ${ }^{13} \mathrm{C}$ NMR (100 MHz): $\delta 20.5\left(\mathrm{CH}_{3}\right), 25.7\left(\mathrm{CH}_{3}\right), 30.9$, $43.5,50.9$.

cis/trans-1,1-Dibromo-2-ethoxy-3-methylcyclopropane From a mixture of $E$ - and $Z$-1-ethoxy-1-propene at $0{ }^{\circ} \mathrm{C}$. The product was isolated as a 80:20 mixture of the cis and trans isomers in $20 \%$ yield by flash chromatography (silica gel, pentane). The low yield was due to instability, which quickly resulted in dehydrobromination. IR: 2980 (w), 1440 (w), 1375 (w), 1232 (m), 1108 (s), 1050 (s), 753 (m) $\mathrm{cm}^{-1} ;{ }^{1} \mathrm{H}$ NMR (90 MHz): $\delta 1.23$ and $1.24(3 \mathrm{H}$, two q in a $4: 1$ ratio, $J 7 \mathrm{~Hz}$ for both isomers), 1.40-1.90 $(1 \mathrm{H}, \mathrm{m}), 3.07$ and $3.50(1 \mathrm{H}$, two d in a $1: 4$ ratio, $J 4.9$ and $8.3 \mathrm{~Hz}$, respectively); ${ }^{13} \mathrm{C}$ NMR $(22.5 \mathrm{MHz}): \delta 10.1$ (cis and trans), 14.8 (cis), 15.5 (trans), 30.4 (cis), 32.7 (trans), 36.0 (cis), 37.2 (trans), 64.5 (cis), 66.7 (cis and trans), 69.4 (trans); MS: $260\left(2, M^{+}\right), 258\left(4, M^{+}\right), 256$ $\left(2, M^{+}\right), 217(7), 215(16), 213(9), 179(40), 178(36)$, 177 (40), 176 (35), 151 (86), 150 (82), 149 (100), 148 (78), 133 (16), 131 (14), 121 (43), 119 (45), 93 (9), 69 (57).

Preparation of acetylenic acetals from 1,1,2- trihalocyclopropanes; general procedure. To a mixture of 1,1,2-trihalocyclopropane (10 mmol), triethylbenzylammonium chloride (TEBA) $(0.2 \mathrm{~g})$, and ethanol $(1.83 \mathrm{~g}, 40 \mathrm{mmol})$ in dichloromethane $(15 \mathrm{ml})$, kept under nitrogen at room temperature, was added $50 \%$ aqueous sodium hydroxide $(6.40 \mathrm{~g}, 80 \mathrm{mmol})$. The resulting mixture was stirred vigorously at room temperature until all the starting material was consumed as shown by gas chromatographic analysis unless otherwise stated (Table 2). Water was added, the products were extracted with ether and were worked up in the usual way. The products were isolated by distillation or flash chromatography. The results are summarized in Table 2.

1,1-Diethoxy-2-propyne (3a), from 1,1,2-tribromocyclopropanes (1a), or from 2-brom-1,1-dichlorocyclopropanes (1b), b.p. $42^{\circ} \mathrm{C} / 22 \mathrm{mmHg}$. IR: 3270 (m), 2970 (s), $2945(\mathrm{~m}), 2896(\mathrm{~m}), 2355(\mathrm{w}), 2120(\mathrm{w}), 1328(\mathrm{~m})$, 1118 (s), 1100 (s), 1055 (s), 1020 (shoulder), 1010 (m) $\mathrm{cm}^{-1} ;{ }^{1} \mathrm{H}$ NMR (400 MHz): $\delta 1.21(6 \mathrm{H}, \mathrm{t}, J 7 \mathrm{~Hz})$, $2.55(1 \mathrm{H}, \mathrm{s}), 3.61(2 \mathrm{H}, \mathrm{m}), 3.76(2 \mathrm{H}, \mathrm{m}), 5.27(1 \mathrm{H}$, s); ${ }^{13} \mathrm{C}$ NMR (100 MHz): $\delta 15.1,61.0,73.4,77.2,91.0$.

3,3-Diethoxy-1-butyne (2b) and 1,1-diethoxy-2-butyne (3b) From 1c, 1d-1f and 1i-1l, b.p. $40^{\circ} \mathrm{C} / 17 \mathrm{mmHg}$ (2b) and b.p. $64^{\circ} \mathrm{C} / 17 \mathrm{mmHg}$ (3b). Ketal 2b: IR: 3282 (m), 3000 (s), 2962 (s), 2875 (m), 2245 (w), 2110 (w), 1440 (m), 1385 (m), 1365 (m), 1220 (s), 1140 (s), 1084 (s), 1047 (s), 944 (s), 850 (s), 690 (s), 652 (s) $\mathrm{cm}^{-1} ;{ }^{1} \mathrm{H}$ NMR (400 MHz): $\delta 1.22(6 \mathrm{H}, \mathrm{t}, J 7 \mathrm{~Hz}), 1.63(3 \mathrm{H}, \mathrm{s}), 2.52$ (1 H, s), 3.57-3.69 (4 H, m); ${ }^{13} \mathrm{C}$ NMR (100 MHz): $\delta$ 
$15.2\left(2 \times \mathrm{CH}_{3}\right), 26.2\left(\mathrm{CH}_{3}\right), 58.3\left(2 \times \mathrm{CH}_{2}\right), 71.9,82.2$, 95.5; MS: 128 (2), 127 (13), 99 (8), 98 (10), 97 (100), 71 (31), 70 (8), 69 (99). Acetal 3b: The spectroscopic and spectrometric data are in keeping with those reported in the literature. ${ }^{4}$

When 1d, 1f, 1j and 11 were used as starting materials, the reaction mixture also contained a third product, formed in better than $15 \%$ yield, and at least three minor products, formed in lower than $5 \%$ total yield. The third product was isolated in 20,15, 12 and $10 \%$ yield, respectively, by flash chromatography of the residue after distillation (silica gel, a 9:1 mixture of hexane:ethyl acetate) and turned out to be 3-ethoxy-2-methyl-2-propenal (11a) on the basis of the following spectroscopic data: IR: 3460 (w), 2970 (s), $2810(\mathrm{~m}), 2770(\mathrm{w}), 2715$ (m), $1708(\mathrm{~m}), 1680-1600$ (broad, s), $1430(\mathrm{w}), 1404(\mathrm{~m})$, $1380(\mathrm{~s}), 1355(\mathrm{~m}), 1300(\mathrm{~s}), 1205(\mathrm{~s}), 1140(\mathrm{~s}), 1100(\mathrm{~s})$, $1000(\mathrm{~s}), 884(\mathrm{~m}), 838(\mathrm{~s}), 726(\mathrm{w}), 693(\mathrm{~m}) \mathrm{cm}^{-1}$; ${ }^{1} \mathrm{H}$ NMR $(200 \mathrm{MHz}): \delta 1.39(3 \mathrm{H}, \mathrm{t}, J 7.1 \mathrm{~Hz}), 1.68$ (3H, broad s), $4.18(2 \mathrm{H}, \mathrm{q}, J 7.1 \mathrm{~Hz}), 7.02(1 \mathrm{H}$, broad s), $9.22(1 \mathrm{H}, \mathrm{s}) ;{ }^{13} \mathrm{C} \mathrm{NMR}(50 \mathrm{MHz}): \delta 5.9\left(\mathrm{CH}_{3}\right), 14.9$ $\left(\mathrm{CH}_{3}\right), 70.6\left(\mathrm{CH}_{2}\right), 119.5(\mathrm{C}), 167.7(\mathrm{CH}), 191.4(\mathrm{C}=\mathrm{O})$.

Aldehyde 11a was subsequently converted to 4-methylisoxazole by treatment with hydroxylamine hydrochloride as described in the literature, but by using THF as solvent. ${ }^{38}$ The product was obtained as an oil. Spectroscopic data for the heterocyclic product were in accordance with the literature. ${ }^{39-41}$

3,3-Diethoxy-3-phenyl-1-propyne (2c) and 3,3-diethoxy1-phenyl-1-propyne $(\mathbf{3 c})$ were obtained from $1 \mathrm{~g}$ and $\mathbf{1 h}$ and were isolated by flash chromatography (silica gel) of a reaction mixture, which also contained a third product, formed in better than $20 \%$ yield, and at least three minor products, formed in lower than $5 \%$ total yield. Ketal 2c and acetal 3c were isolated as mixtures (Table 2) using a 9:1 mixture of hexane:ethyl acetate as eluent and analyzed spectroscopically. IR: $3290(\mathrm{w}), 2960$ (m), 2890 (m), $2240(\mathrm{w}), 1485$ (m), 1442 (m), 1355 (m), $1330(\mathrm{~m}), 1235(\mathrm{~m}), 1090$ (s), 1045 (s), 1005 (s), 755 (m) $\mathrm{cm}^{-1}$; ${ }^{1} \mathrm{H}$ NMR $(90 \mathrm{MHz}): \delta 1.15-1.38(6 \mathrm{H}, \mathrm{m})$, $2.66(0.9 \mathrm{H}, \mathrm{s}), 3.30-4.00(4 \mathrm{H}, \mathrm{m}), 5.12(0.1 \mathrm{H}, \mathrm{s})$, $7.20-7.75(5 \mathrm{H}, \mathrm{m}) ;{ }^{13} \mathrm{C}$ NMR $(22.5 \mathrm{MHz}): \delta 15.1$ $\left(2 \times \mathrm{CH}_{3}, 2 \mathrm{c}\right), 15.2\left(2 \times \mathrm{CH}_{3}, 3 \mathrm{c}\right), 58.7\left(2 \times \mathrm{CH}_{2}, 2 \mathrm{c}\right)$, $61.0\left(2 \times \mathrm{CH}_{2}, 3 \mathrm{c}\right), 74.1$ (3c), $82.0(2 \mathrm{c}), 84.6(3 \mathrm{c}), 85.2$ (2c), 91.9 (3c), 97.1 (2c), 122.1, 126.6, 128.1, 128.3, 128.6, 128.8, 131.9, 140.3; MS (2c): $204\left(0.2, M^{+}\right), 203$ (0.3), $176(2), 175(1), 160(14), 159(100), 132(8), 131$ (70), 115 (7), $105(9), 103(11), 102$ (18), 91 (2), 77 (17); MS (3c): $204\left(1, M^{+}\right), 203$ (2), 176 (5), 175 (33), 160 (26), 159 (96), 147 (11), 133 (21) 132 (100), 131 (25), 130 (42), 119 (11), 115 (11), 105 (2), 103 (46), $102(44), 91$ (11), 77 (31).

When $2 c$ and $3 c$ had been eluted the third product was subsequently isolated by changing the eluent to ethyl acetate. The yield of the third product was 20 or $45 \%$ when the starting material was $\mathbf{1 g}$ or $\mathbf{1 h}$, respectively. The product was proved to be 3-ethoxy-2-phenyl-2- propenal (11b) on the basis of the following spectroscopic data: IR: 3045 (w), 3010 (w), 2960 (m), 2645 (w), 2520 (w), $1680(\mathrm{~s}), 1588(\mathrm{~m}), 1575(\mathrm{w}), 1483(\mathrm{w}), 1438(\mathrm{~m})$, 1403 (m), 1308 (m), 1277 (s), 703 (s) $\mathrm{cm}^{-1} ;{ }^{1} \mathrm{H}$ NMR (90 MHz): $\delta 1.38(3 \mathrm{H}, \mathrm{t}, J 7 \mathrm{~Hz}), 4.19(2 \mathrm{H}, \mathrm{q}, J 7 \mathrm{~Hz})$, $7.10(1 \mathrm{H}, \mathrm{s}), 7.20-7.70(5 \mathrm{H}, \mathrm{m}), 9.38(1 \mathrm{H}, \mathrm{s}) ;{ }^{13} \mathrm{C}$ NMR (22.5 MHz): $\delta 15.2\left(\mathrm{CH}_{3}\right), 72.0\left(\mathrm{CH}_{2}\right), 122.6(\mathrm{C}), 127.4$ $(\mathrm{CH}), 127.9(2 \times \mathrm{CH}), 129.3(2 \times \mathrm{CH}), 130.9(\mathrm{C}), 168.5$ $(\mathrm{CH}), 190.6(\mathrm{C}=\mathrm{O})$; MS: $177\left(12, M^{+}\right), 176\left(100, M^{+}\right)$, 148 (29), 132 (7), 120 (58), 105 (6), 104 (7), 103 (18), $102(29), 92(12), 91$ (82), 78 (13), 77 (16). A conceivable alternative aldehyde structure 2-ethoxy-3-phenyl-2-propenal can be ruled out based on available ${ }^{1} \mathrm{H}$ NMR data. $^{43}$

Aldehyde 11b was subsequently converted to 4-phenylisoxazole by treatment with hydroxylamine hydrochloride as described in the literature, but by using THF as solvent. ${ }^{38}$ The product was obtained as a solid, m.p. $45-46{ }^{\circ} \mathrm{C}$ (lit. ${ }^{38}$ m.p. $46-47^{\circ} \mathrm{C}$ ) and exhibited spectroscopic data in accordance with the literature..$^{39,41,42}$

2,2-Diethoxy-3-pentyne (2d) as a single product from $1 \mathrm{~m}-1$ p, b.p. $62-66^{\circ} \mathrm{C} / 20 \mathrm{mmHg}$. IR: 2970 (s), 2930 (m), 2890 (w), 2245 (w), 1442 (w), 1388 (m), $1370(\mathrm{~m}), 1260$ (s), $1223(\mathrm{w}), 1155$ (s), 1120 (m), 1090 (m), 1057 (s), $1025(\mathrm{w}), 945(\mathrm{~m}), 855(\mathrm{~m}), 695(\mathrm{w}) \mathrm{cm}^{-1} ;{ }^{1} \mathrm{H}$ NMR (400 MHz): $\delta 1.21(6 \mathrm{H}, \mathrm{t}, J 7 \mathrm{~Hz}), 1.60(3 \mathrm{H}, \mathrm{s}), 1.87$ (3 H, s) $3.51-3.67(4 \mathrm{H}, \mathrm{m})$; ${ }^{13} \mathrm{C}$ NMR $(100 \mathrm{MHz}): \delta$ $3.5\left(\mathrm{CH}_{3}\right), 15.3\left(2 \times \mathrm{CH}_{3}\right), 26.4\left(\mathrm{CH}_{3}\right), 57.7\left(2 \times \mathrm{CH}_{2}\right)$, 78.2 (C), 80.1 (C), 95.8 (C).

The product was then converted into the corresponding 2,4-dinitrophenylhydrazone by treatment with an acidic $\left(\mathrm{H}_{2} \mathrm{SO}_{4}\right)$ methanol solution of 2,4-dinitrophenylhydrazine, m.p. $150-152^{\circ} \mathrm{C}$. IR $\left(\mathrm{CHCl}_{3}\right): 3250$ (w), 3040 (w), 2950 (w), 2205 (w), 1605 (s), 1583 (s), $1498(\mathrm{~m}), 1410(\mathrm{~m}), 1328$ (s), 1300 (s), $1128(\mathrm{~m}), 1092$ (m) $\mathrm{cm}^{-1} ;{ }^{1} \mathrm{H}$ NMR (400 MHz): $\delta 2.22(3 \mathrm{H}, \mathrm{s}), 2.27$ (3 $\mathrm{H}, \mathrm{s}), 7.89(1 \mathrm{H}, \mathrm{d}, J 9.8 \mathrm{~Hz}), 8.27(1 \mathrm{H}, \mathrm{dd}, J 2.4$ and $9.8 \mathrm{~Hz}), 9.11(1 \mathrm{H}, \mathrm{d}, J 2.4 \mathrm{~Hz}), 11.81(1 \mathrm{H}, \mathrm{br}$ s, NH); ${ }^{13} \mathrm{C}$ NMR $(100 \mathrm{MHz}): \delta 4.5,22.5,72.3,103.1,116.6$, $123.4,129.1,129.8,137.1,137.9,144.1$.

Ring opening of cis/trans-1,1-dibromo-2-ethoxy-3-methylcyclopropane under PTC gave a black reaction mixture, from which a single isomer (most likely with $Z$ configuration, see discussion) of 2-bromo-1,1-diethoxy-2-butene (10) was isolated in $22 \%$ yield by flash chromatography (silica gel, 8:2 pentane-dichloromethane). IR: $2960(\mathrm{~m})$, $1640(\mathrm{~m}), 1365$ (w), $1250(\mathrm{~m}), 1155(\mathrm{~s}), 1060(\mathrm{~m}), 810$ (w), $710(\mathrm{~m}) \mathrm{cm}^{-1} ;{ }^{1} \mathrm{H}$ NMR $(90 \mathrm{MHz}): \delta 1.00-1.35(6$ $\mathrm{H}, \mathrm{m}), 1.75(3 \mathrm{H}, \mathrm{d} \times \mathrm{d}, J 0.8$ and $6.6 \mathrm{~Hz}), 3.20-3.70$ (4 $\mathrm{H}, \mathrm{m}), 4.74(1 \mathrm{H}$, broad s), $6.26(1 \mathrm{H}, \mathrm{q} \times$ broad s); ${ }^{13} \mathrm{C}$ NMR $(22.5 \mathrm{MHz}): \delta 15.1\left(2 \times \mathrm{CH}_{3}\right), 16.1\left(\mathrm{CH}_{3}\right)$, $61.9\left(2 \times \mathrm{CH}_{2}\right), 102.5(\mathrm{CH}), 125.4(\mathrm{C}), 127.0(\mathrm{CH})$.

When a sample of 2-bromo-1,1-diethoxy-2-butene was exposed to slightly acidic water a single isomer (most likely with $\mathrm{Z}$ configuration) of 2-bromo-2-butenal was 
obtained. IR: $1690 \mathrm{~cm}^{-1} ;{ }^{1} \mathrm{H}$ NMR $(90 \mathrm{MHz}): \delta 2.15(3$ $\mathrm{H}, \mathrm{d}, J 6.6 \mathrm{~Hz}), 7.26(1 \mathrm{H}, \mathrm{q}, J 6.6 \mathrm{~Hz}), 9.22(1 \mathrm{H}, \mathrm{s})$.

Acknowledgement. Financial support from the Norwegian Research Council, Norsk Hydro and Borregaard Fine Chemicals is gratefully acknowledged.

\section{References}

1. Hendrick, R. A. and Moss, R. A., Tetrahedron Lett. (1979) 4249.

2. Baird, M. S., Buxton, S. R. and Whitley, J. S., Tetrahedron Lett. 25 (1984) 1509.

3. Baird, M. S., Hussain, H. H. and Nethercott, W., J. Chem. Soc., Perkin Trans. 1 (1986) 1845.

4. Pettersen, A., Jørgensen, E. and Sydnes, L. K., Acta Chem. Scand. 44 (1990) 603.

5. Makosza, M. and Fedorynski, M., Synth. Commun. 3 (1973) 305.

6. Dehmlow, E. V. and Wilkenloh, J., J. Chem. Res. (S) (1984) 396.

7. Dehmlow, E. V., Thieser, R., Sasson, Y. and Pross, E., Tetrahedron 41 (1985) 2927.

8. Makosza, M. and Wawrzyniewicz, W., Tetrahedron Lett. (1969) 4659.

9. Baird, M. S., Nethercott, W. and Slowey, P. D., J. Chem. Res. (S) (1985) 370; J. Chem. Res. (M), (1985) 3815.

10. Skell, P. S. and Cholod, M. S., J. Am. Chem. Soc. 91 (1969) 6035.

11. Skell, P. S. and Cholod, M. S., J. Am. Chem. Soc. 91 (1969) 7131.

12. Nefedov, O. M. and Shafran, R. N., Izv. Akad. Nauk SSSR, Ser. Khim. (1965) 538.

13. Jonczyk, A. and Balcerzak, P., Tetrahedron Lett. 30 (1989) 4697.

14. Balcerzak, P., Fedorynski, M. and Jonczyk, A., J. Chem. Soc., Chem. Commun. (1991) 826.

15. Balcerzak, P. and Jonczyk, A., J. Chem. Res. (S) (1994) 200.

16. Tobey, S. W. and West, R., J. Am. Chem. Soc. 86 (1964) 56.

17. Skell, P. S. and Garnes, A. Y., J. Am. Chem. Soc. 78 (1956) 5430.

18. Sæthre, L. J. and Sydnes, L. K. To be published.

19. Nerdel, F., Buddrus, J., Windhoff, J., Brodowski, W.,
Klamann, D. and Ulm, K., Liebigs Ann. Chem. 710 (1967) 77.

20. Dehmlow, E. V., Chem. Ber. 101 (1968) 410.

21. Zahra, J. P. and Waegell, B., Tetrahedron Lett. (1970) 2537.

22. Raulet, C., C. R. Acad. Sci. Paris 287 (1978) 337.

23. Billups, W. E., Blankeney, J., Rao, N. A. and Buynak, J. D., Tetrahedron 37 (1981) 3215.

24. Baird, M. S. and Nethercott, W., Tetrahedron Lett. 24 (1983) 605.

25. Seyferth, D. and Julia, T. F., J. Organometal. Chem. 14 (1968) 109.

26. Henseling, K.-Q., Quast, D. and Weyerstahl, P., Chem. Ber. 110 (1977) 1027.

27. Skattebøl, L., J. Org. Chem. 31 (1966) 1554.

28. Müller, P and Pautex, N., Helv. Chim. Acta 74 (1991) 55.

29. Halton, B., Bridle, J. H. and Lovett, E. G., Tetrahedron Lett. 31 (1990) 1313.

30. Billups, W. E., Lin, L. P. and Chow, W. Y., J. Am. Chem. Soc. 96 (1974) 4026.

31. Billups, W. E., Reed, L. E., Casserly, E. W. and Lin, L. P., J. Org. Chem. 46 (1981) 1326.

32. Müller, P. and Nguyen-Thi, H.-C., Helv. Chim. Acta 67 (1984) 467

33. Dent, B. R. and Halton, B., Tetrahedron Lett. 25 (1984) 1313.

34. Göthling, W., Keyaniyan, S. and de Meijere, A., Tetrahedron Lett. 25 (1984) 4101.

35. Kostikov, R. and de Meijere, A., J. Chem. Soc., Chem. Commun. (1984) 1528.

36. Al Dulayymi, J. R., Baird, M. S. and Fitton, H. L., Tetrahedron Lett. 33 (1992) 4803.

37. Al Dulayymi, J. R., Baird, M. S., Fitton, H. L. and Rajaram, L., J. Chem. Soc., Perkin Trans. 1. (1994) 1633.

38. Munno, A. D., Bertini, V. and Lucchesini, F., J. Chem. Soc., Perkin Trans. 2 (1977) 1121.

39. Katritzky, A. R. and Boulton, A. J., Spectrochim. Acta 17 (1961) 238.

40. Lombardi, E., Segre, A., Bertini, V. and Pino, P., Chim. Ind. (Milan) 46 (1964) 206.

41. Pouchan, C., Senez, S., Raymond, J. and Sauvaitre, H., J. Chim. Phys. Physicochim. Biol. 71 (1974) 525.

42. Sokolov, S. D., Yudintseva, I. M. and Petrovskii, P. V., Zh. Org. Khim. 6 (1970) 2584.

43. Ferdinand, G. and Schank, K., Synthesis (1976) 404.

Received September 11, 1995. 